\title{
The Technology of Dramatization as a Creative Method of Teaching English as a Foreign Language (by an Example of a Special Course "English Theatre")
}

\author{
Shayakhmetova Leysan Khabirovna \\ Mukhametzyanova Leilya Ruslanovna
}

\author{
Kazan Federal University (Russia)
}

Email: habirshah@mail.ru

Doi:10.5901/mjss.2015.v6n3s1p296

\begin{abstract}
The article represents the dramatization technology as a means of foreign language teaching in terms of the special course introduction at the Department of Art, describes the goals, objectives and content of the course and proves the effectiveness of this technology.
\end{abstract}

Keywords: teaching technology, dramatization, drama activities, creative teaching, theatre pedagogy.

The development of theatre gives a powerful impetus to formation of aesthetic perception of the world, advances an ability to emphasize and to feel, inspires a creative development and transformation of reality, spiritual attitude to life and, in general, forms a creative and moral person. The aesthetic education through acting involves a wide range of methods to affect the consciousness of the audience. Acting influences a soul, emotions and a mind of a spectator, affects not only the consciousness but also the subconsciousness. An aesthetic image, created by an actor and his expressive and impressive speech, is an effective technique to have an impact on the audience. And this is a motive to use a stage for development and improvement of communicative skills in a foreign language. English language is one of the main subjects in a curriculum, and acting in a foreign language gives an excellent opportunity to broaden and deepen the knowledge. And it determines the relevance of this study.

The technology of dramatization definitely belongs to a range of creative methods of teaching foreign languages, some of which have been studied by O.F. Ostroumova, L.R. Nizamieva, G.I. Nazarova in their research "The didactic aspect of foreign language creative teaching" (Ostroumova, 2014, pp. 76-82), since the use of dramatization during lessons creates a necessary intercultural coloring, gives an opportunity to introduce students to another culture, traditions of other countries, regarding a lifestyle and a behavior in different situations, etc. With proper organization of activities these classes can inspire to express creative abilities, diversify emotions and help to overcome difficulties in communication.

In methodological literature we find the following terms of dramatization: staging, acting, performance, an educational theatre, a training theatre, theatricalization (Kuzmenkova, 2002, pp.50-54). Consequently, under the term "dramatization" in a foreign language learning process we mean "a creative use of written and oral speech on the basis of a literary work" (Ibsen, 1993, pp. 143-153].

We agree with the interpretation given by R.V. Fastovets, who defines dramatization as one of modern social technologies, a kind of role-playing, implemented in two possible ways: by transformation of a monologue into a dialogue or by staging a one-act play based on a literary work (Фастовец, 2002, c.235-239). R.V. Fastovets considers that as a variety of role-playing, dramatization has the following components:

- a communicative situation, including the communicational content (a subject, a product and a result), and communicational conditions, including para- and extralinguistic means of communication, temporal and spatial characteristics;

social roles of communicators and a system of their personal relationships;

- a social technique of communication, implementation of a situation, specific speech functions and a communicative technique (starting and completing the act of communication, communicative distribution and communicative role-changing, conversation maintenance, control of information transmission, clarification, correction and self-correction).

Dramatization as a methodical approach to language studies was first used in England. Peter Slade and Brian Way 
are considered to be the progenitors who first used this technique at school (Dodds, 2004). Their idea of dramatization as a means to form a creative personality of students had an impact on further development of methodological theories based on the use of dramatization in a learning process. P. Slade and B. Way believed that traditional school exercises "destroy spontaneity and creativity of children". Their exercises with elements of dramatization were directed to develop imagination and feelings of students, to use gestures and facial expression; and assignments involved verbal interaction of partners in real communicative situations. Many of them are used today as speech exercises for a purpose to create an atmosphere of international communication or as relaxation means.

In 1979 Gavin Bolton and Dorothy Heathcote established "The Newcastle School", which aim was to teach the language with use of dramatization (Farmer, 2010). Theatre was a form of art which became the basis for improvisation created by joint efforts of a teacher and students. And the teacher's role gave him an opportunity to control the process from the inside, not just give instructions to the students.

S. Holden (1981), A. Mali and A. Duff (1978), B. Wagner (1998) and others were working on development of drama in language studies.

The idea of implementation of certain elements of theatre pedagogy as learning tools is not new for us. Professor I.A. Zyazyun in his educational course "The fundamentals of pedagogic skills" covers such topics as "elements of acting and directing in a pedagogic activity", "stages of preparation for speech action", "expressiveness of a teacher's speech" and etc (Зязюн, 1989).

Dramatization is a technique that can directly contribute to full perception of literature, development of "literary" reproductive imagination, as it involves understanding of the characters' motives, the meaning given by an author.

Russian methodology of using the elements of theatre pedagogy is based on Stanislavsky's system (Станиславский, 1989, с. 511). The system created by K.S. Stanislavsky is one of the most important achievements in theatre pedagogy, in its full meaning, including the relations of all its constituent elements. But of course it cannot be applied in a high school. This system pursues a different aim which is the training of professional actors. In order to use drama as a learning tool in language studies we need to understand the main elements of acting, to take the most necessary of them and apply them for our purposes.

As a scientific theory of acting, Stanislavsky's system is a serial circuit of pedagogic techniques and methods, which help to acquire the skill of an actor's speech and to make it active, efficient and purposeful. Dramatization is a students' activity on comprehension of the deep essence of a literary work. Therefore, the use of certain provisions of Stanislavsky's system related to language studies can become a logical and pedagogically appropriate tool.

The main provision of the Stanislavsky's system is an idea of a super-objective. The super-objective according to K.S. Stanislavsky is the world view of an artist. An interpreter of a literary work, being a director or an actor, always complements, enriches and nourishes a performance with his own understanding. The main objective of a dramatist (and his super-objective) finds an echo in souls of actors and directors. Through ideas of the dramatist a director and actors reveal their own attitude to any vital phenomenon depending on their own world view.

In a daily life the unity of thought, will and feelings appear in human speech naturally, while in reading, especially in a foreign language, this unity does not always exist or not in the same degree of comprehension. A reader deals with a finished text, which is not always an expression of his own thoughts. He pronouns words without proper penetration into the author's ideas, without clear understanding of a phenomena which stimulated these thoughts. In this case the unity of the reader's thoughts, will and feelings does not appear. Reading does not fulfill the main function of speech - a communicational function, does not reveal an ideological and emotional essence of the work.

The reader's unity of thoughts, feelings and volitional orientation appears in a verbal action. K.S. Stanislavsky came to the conclusion that a living word could become the result of an extensive preparatory work. In order to make the author's text more personal and the speech more effective he offered to study the author's way of thinking in details so the reader would be able to express the idea using his own words. And that is exactly what we should teach in a classroom at the lessons of home reading with the use of dramatization. Getting absorbed in a content of the text students will be getting inspired by the author's thoughts and feelings and experience them as their owns. The entire impression of a literary work, and all thoughts, feelings, experience, emotional assessments and volitional aspirations caused by them, form the so-called performing subtext, which expresses the interpretation of the work. Revealing the subtext the reader makes it his living word.

V.A. Artemov pointed out that conditions, which influence the development of language skills, are extremely close to conditions on a stage. He considered that "the given conditions" are substantial for language acquisition (Артемов, 1969). He wrote: "Acting allows, at a certain degree, to reveal social and psychological mechanisms of speech activity regulation. Theatre in this case can be considered as a laboratory where the speech activity is developed. At the same time theatre has a theory of speech activity as a set of elements, which helps to recreate an image of a character. This 
real life recreation process on the stage is so true that sometimes it can be more effective than our daily life". The given conditions contained in a literary work create motives and needs for verbal actions, impersonation involves mobilization of personal qualities, not only the ego but also the alter ego ("the I" of a character) appears under these conditions.

Acting makes students pass the situation through, giving it a personal characteristic. As the experience of foreign language studies demonstrates, personal orientation greatly enhances the effect of assimilation, as in this case emotions are connected with intelligence. A role can make a situation personally significant for a student.

When role-playing a student starts to speak his character's language, becomes the character for several moments, acting leaves a stronger and more lasting impression. Consequently, the main value of dramatization is that it "gives an opportunity to get acquainted with a literary work more closely. Acting promotes a better understanding of a literary passage through impersonation". And that is exactly what we strive by teaching students read and speak in a foreign language.

Dramatization in language studies is considered as a unique technique that improves both speech and language skills, and gives a deeper understanding in other areas, as literature and psychology.

Dramatization as a technique for language teaching helps to develop social knowledge, linguistic consciousness, to foresee the students' needs and interests, to encourage students with a different language level to speak the language. Besides, dramatization develops critical and intuitive thinking, it stimulates better focusing, and forms reading skills. Acting helps to increase vocabulary, develops communicative skills and affords aesthetic pleasure. Psychologists are at one in thinking that emotional empathy is remembered and comprehended better than something neutral, indifferent. That is why a foreign language teacher should intervene actively in the emotional atmosphere at the lesson, and ensure, if possible, emotional states, favorable for the learning activity. The use of untraditional educational methods and techniques helps to involve the emotional sphere of consciousness as untapped reserves for creative development of a person (Зимняя, 1991, с. 223).

Implementation of a special course "English theatre" is governed by a necessity to form communicative competence in order to provide communication when acting, it allows students to use their knowledge and skills in real life situations.

The specific character of the course requires not only intellectual, but also material costs (design of costumes, decorations, posters, music, sound and choreographic elements and etc.). And implementation of this course in the curriculum of fine arts students - future artists, designers, musicians and choreographers - will reveal the creative potential of students.

The educational program has the following aims:

Educational: social development of a personality; extension of knowledge on the subject, vocabulary expansion, acquiring of a broad linguistic and cultural information, comprehensive use of tenses studied within the course in monologues and dialogues, pronunciation training and work on phonetic difficulties and etc.

Developing: development and improvement of oral communicative skills; formation of a personality ready for intercultural communication; development of memory, thinking, attention, acting skills; development of an intellectual, emotional and communicational activity.

Pedagogical: formation of students' personal traits needed for successful socialization; development of an ability to be a team member, development of socio-cultural competence; comprehensive development of a personality by means of a foreign language; identification and development of creative abilities of gifted students.

The main goals of the program are:

motivation of students to learn English;

- improvement of aesthetic perception and arrangement of conditions for realization of a creative potential, conservation and enhancement of cultural, creative traditions of students;

formation of tolerance and enhancement of moral values under the conditions of a modern life;

- development of observation, attention, willpower, imagination, creative initiative, culture of speech, emotional response to the foreign speech, in particular through a study of English folklore, learning of poems and songs, etc.

The program is designed for students who study English as an additional specialization and planned for the $3 \mathrm{~d}$ and the $4^{\text {th }}$ educational terms.

Performance staging consists of the following stages:

1. Acquaintance with a history of the English theatre.

2. Acquaintance with literature through extracts of plays.

3. Work with monologues and dialogues.

4. Etudes - the second level, when students are encouraged to create simple situations with characters and play 
them. There are several types of etudes: a single etude on emotional recollection and on a physical state; a single or a companion etude on an action with imaginary objects; group etudes on verbal expression.

5. Selection of a literary work; analysis of lexical and grammatical materials.

6. Allocation of roles and role-learning. Stage setting. Choreographic and vocal training.

7. Repetitions (students fill their roles with a meaning, expressed by intonations, sense pauses, facial expressions and gestures). The stage is divided into episodes - each of them is trained separately.

8. Rehearsals (from the same beginning to the same end of a performance with all music, sound and choreographic effects).

9. Running rehearsals (non-stop rehearsals). Teacher makes all remarks and clarifications after a running rehearsal.

10. Dress rehearsal.

11. Premiere (an official presentation of a play to the audience).

12. Writing of essays on the topic of a play.

Preparation of each dramatization activity involves a study of themes and educational situations, including:

1. Thematic section where the basic content of a theme (staged English legends and fairy tales, plays of W. Shakespeare and B. Show, staged books of A. Christy, M. Twain, A.K. Doyle and others) is defined; a new vocabulary is introduced and trained; communication, listening, reading and writing skills are formed.

2. Language and speech section where a teacher offers additional exercises for training of both language (lexical, grammatical, phonetic) and communicative skills and abilities in different communication situations, mainly in a form of dialogic speech on a wide range of problems.

3. Linguistic and cultural section, which helps students to get more information on English-speaking countries and the entire world, to compare linguistic and cultural peculiarities in different countries.

4. Independent work, used to secure figures of speech and phraseological combinations which have been studied (students translate the extracts of dramatic works of Russian and Tatar literature into English).

5. Student projects prepared in small groups using skills of a verbal and a non-verbal nature. Each performance is a completed students' project.

The special course "English theatre" generates the following competences:

1) Communicative competence, which includes knowledge and use of the English language, improving of skills, vocabulary broadening, development of memory and fluency.

2) Personal self-improvement which involves spiritual and intellectual self-development of students.

3) Informational competence, which is formed during studies of the English theatre history.

4) General cultural competence, developed at the level of costumes and decorations designing.

5) Axiological competence which is being formed through text, monologue, dialogue studies, while discussing the characters.

6) At theatre students try their hand at different roles, which contributes to their self-determination and further self-actualization. Thereby a social competence is being developed.

As a result language studies within the special course "English theatre" a student should know/understand:

- definitions of new lexical units, related to the main theme and communication situations, including assessment vocabulary, clichés and etiquette, which reflect the peculiarities of a country/countries of the language; definitions of the studied grammatical phenomena;

- cultural and geographical information from authentic sources, which can enrich the social experience of students: information on a country/countries of the studied language, their literature and culture, poets and writers.

- A student should be able to use the acquired skills and knowledge in practical activities of his daily life:

- communication with representatives of other countries, orientation in a modern multicultural world;

- study of modern values of the world culture, cultural heritage and other countries achievements; presentation of culture and achievements of Russia and Tatarstan to representatives of foreign countries.

The independent work of students plays an important role in preparation for practical work. In order to increase the effectiveness the students are encouraged to read foreign literature (in original), analyze it, compare, select certain plays and fairy tales and etc. that can be used as the basis for script-writing and further performing.

Students are advised to select the most interesting works in English, to work on them properly, using dictionaries for definition and clarification of unknown words, to make up "a portfolio" (a methodological folder) which will assist students during their pedagogic training at elementary schools and during their further professional activity. Students fill their portfolio with interesting stories, fairy tales, poems, songs and scripts for different performances and festivals. 
Thus, one of the ways to intensify the learning process and to improve the level of language skills is a technology of dramatization, as it can liven up the power of thinking and creative abilities of students, allows to make the learning process more interesting and entertaining.

\section{References}

Dodds Harry (2004). Peter Slade - the first British dramatherapist. The Gardian. Friday, 20 August from http://www.theguardian.com/ news/2004/aug/20/guardianobituaries.artsobituaries1

Farmer David. Drama resourse. Dorothy Heathcote. from http://dramaresource.com/resources/features/335-dorothy-heathcote

Holden Susan (1981). Drama in Language Teaching (Longman handbooks for language teachers). Longman.

Ibsen, I.B. (1993) The Double Role of Fiction in Foreign Language Learning: Towards a Creative Methodology. Creative Classroom Activities. Selected Articles from the English Teaching Forum, 1989 - 1993. - pp 143-153.

Kuzmenkova, J. (2002). ELT Theatre - a New Approach to Drama Activities. Bulletin of Moscow University. - Series 19: Linguistics and Intercultural Communication. - № 3.- pp 50-54.

Maley A., Duff A. (1982) Drama techniques in language learning. Cambridge University Press.

Ostroumova O.F., Nizamieva L.R., Nazarova G.I. (2014) The didactic aspect of foreign language creative teaching. Journal of language and literature. 5(3), 76-82. DOI: 10.7813/jll.2014/5-3/14

Wagner B. J. (1998). Educational Drama and Language Arts: What Research shows. Portsmouth, Heinemann.

Wagner B.J. (1979). Dorothy Heathcote: Drama as a Learning Medium. London, Hutchinson.

Артемов В.А. (1969). Психология обучения иностранным языкам (гл. 1-4), М., «Просвещение».

Зимняя И.А. (1991). Психология обучения иностранным языкам в школе, М.: Просвещение, сс 223.

Зязюн И.А. (1989). Основы педагогического мастерства: учеб. пособ. для пед. спец. высш. учеб. заведений, М., Просвещение.

Станиславский К. (1989). С. Собрание сочинений: В 9 m. Т. 2. Работа актера над собой. Часть 1: Работа над собой в творческом процессе переживания: Дневник ученика, М.: Искусство, сс 511.

Фастовец Р.В. (2002) Игры по правилам: социальные технологии в практике обучения иностранным языкам. Непрерывное обучение иностранным языкам: методология, теория, практика: мат. Междунар. науч.-практ. конф. М.: МГЛУ. Ч. 1. сс 235239. 